\title{
PERANCANGAN SYSTEM INFORMASI PENANGANAN KELUHAN KONSUMEN BERBASIS WEB PADA PT. INDUSTIRA BATU CEPER TANGERANG
}

\author{
Rosmawati Dwi ${ }^{* 1,}$ Sinudarwati $^{2}$, Fika Regita Trismiyanto ${ }^{3}$ \\ ${ }^{1}$ Program Studi Sistem Informasi Universitas Raharja, ${ }^{2}$ Program Studi Sistem Informasi \\ Universitas Raharja, ${ }^{3}$ Program Studi Mahasiswa Sistem Informasi Universitas Raharja ${ }^{3}$ \\ e-mail: *1'rosmawati.dwi@ raharja.info, ${ }^{2}$ sinudarwati@ raharja.info, ${ }^{3}$ fika.regita@ raharja.info
}

\begin{abstract}
Abstrak
PT Industira adalah salah satu perusahaan yang bergerak di dalam bidang manufaktur panel listrik pembagi (Disribution Board) untuk penerangan lampu TL. Untuk meningkatkan pelayanan kepada konsumen, PT Industira menyediakan bagian Quality Assurance \& Customer Service Team Leader (QA \& CS TL) sebagai wadah untuk menampung berbagai penanganan keluhan yang diberikan oleh konsumen. Berdasarkan sistem berjalan diperoleh hasil bahwa sistem masih terdapat beberapa kekurangan yang semuanya masih dilakukan secara manual sehingga perlu adanya sistem baru yang lebih akurat yaitu sistem informasi keluhan konsumen berbasis web yang menggunakan pemrograman PHP dengan Notepad++ dan pembuatan database dengan MySql. Dari proses tersebut dihasilkan sebuah sistem keluhan konsumen berbasis web yang dapat mengurangi terjadinya ketidakefektif dan ketidakefesienan dalam penyampaian keluhan, penampungan keluhan, pengolahan data keluhan, pengambil keputusan sampai dengan penyusunan laporan keluhan sehingga dalam seluruh proses penanganan keluhan termonitoring dengan baik.
\end{abstract}

Kata Kunci Pelayanan, keluhan, Sistem Informasi

\section{Abstract}

PT Industira is one of the companies engaged in manufacturing Disassembly power panel (Disribution Board) for TL lamp lighting. To improve costumer service, PT Industira provides Quality Assurance \& Customer Service Team Leader (QA \& CS TL) as a container to accommodate various complaints handling provided by consumers. Based on the current system obtained the results that the system there are still some disadvantages are all still done manually that need a more accurate new system that is a web-based consumer complaint information system that uses PHP programming with Notepad ++ and MySql database creation. From the process is generated a web-based consumer complaints system that can reduce the ineffectiveness and inefficiency in the delivery of complaints, grievance shelter, data processing complaints, decision makers to the preparation of complaints so that the entire process of handling complaints properly monitored.

Keywords Services, complaints, Information Systems 


\section{Pendahuluan}

Salah satu faktor yang menjadikan teknologi semakin dibutuhkan adalah meningkatnya kebutuhan informasi yang sangat beragam. Penyajian informasi yang efektif dan tepat akan menjadikan performa sebuah instasi/perusahaan organisasi semakin berkualitas. PT. Industira adalah salah satu perusahaan yang bergerak didalam bidang manufaktur panel listrik pembagi (Disribution Board) untuk penerangan lampu TL (Tube Lamp). Untuk meningkatkan pelayanan kepada konsumen, PT. Industira menyediakan bagian Quality Assurance \& Costumer Service Team Leader (QA \& CS TL) sebagai wadah untuk penanganan keluhan dari konsumen berkaitan dengan lemahnya tanggung jawab, lambatnya penanganan dari staff perusahaan, kualitas barang, kerusakan barang, keterlambatan pengiriman barang dan perbaikan pelayanan. Terdapat beberapa keluhan yang penangananya harus tersitematis sehingga diharapkan dapat membantu mengurangi permasalahan perusahaan untuk dapat bersaing dengan perusahaan lain dalam kondisi pasar bersaing.

\section{Metode Penelitian}

1. Metode Pengumpulan Data

Metode dengan cara mengumpulkan data mengenai keadaan secara langsung dari lapangan atau tempat yang menjadi obyek penelitian penulis untuk mendapatkan data secara relevan

2. Metode Analisa Sistem

Metode analisa SWOT (Strengths, Weakness, Opportunities, Threats) yang digunakan untuk mengidentifikasi, mengevaluasi dan memecahkan masalah yang ada pada PT. Industira Batu Ceper Tangerang

3. Metode Perancangan Sistem

Metode perancangan yang digunakan yaitu UML (Unified Modeling Language), UML merupakan salah satu alat bantu yang digunakan dalam bahasa pemrogaman yang berorientasi objek, bahasa yang telah menjadi standar untuk visualisasi, menetapan, membangun dan mendokumentasikan arti suatu sistem perangkat lunak

4. Metode Pengujian (Testing)

Dalam pengujian peneliti yaitu Blackbox testing. Black box testing adalah pengujian yang berfokus pada spesifikasi fungsional dari perangkat lunak, oleh karena itu uji coba black box testing memungkinkan perangkat lunak untuk membuat kumpulan kondisi input dan melakukan pengetesan pada spesifikasi fungsional program.

\section{LITERATURE REVIEW}

1. Penelitian International Journal yang dilakukan oleh Doga Istanbulluoglu (September, 2017) University of Birmingham Vol. 7 halaman 72-82. Penelitian ini berjudul "Complaint Handling On Sosial Media : The Impact Of Multiple Response Times On Consumer Satisfaction". The focus of this the paper explores how the complaint response time on social media influences consumer satisfaction with complaint handling, consumers expect companies to replay to their complaint within 1-3 h on twitter and within 3-6 $\mathrm{h}$ on facebook, both quicker first response and quicker conclusive response lead to higher satisfaction with complaint handling. 
2. Penelitian skripsi yang dilakukan oleh Gerizky Saputra (2016) Fakultas Teknik Universitas Muhammadiyah Yogyakarta. Penelitian ini berjudul "Perancangan Sistem Penanganan Keluhan Berbasis Web" tujuan dari penelitian yang dilakukan yaitu untuk menampung keluhan secara online yang digunakan mahasiswa dalam memberikan keluhan atau aspirasi mahasiswa berdasarkan kategori, dan untuk admin program studi dapat memberikan tanggapan dalam bentuk notification bahwa pengaduan atau keluhan sudah di tangani dan dapat dilihat oleh mahasiswa.

3. Penelitian skripsi yang dilakukan oleh Edi Wibowo (2016) STMIK Raharja. Penelitian ini berjudul "Perancangan Sistem Informasi Aplikasi Manajemen Komplain Costumer pada Departemen Customer Service PT Duta Abadi Primantara Pangerang". Pada penelitian ini penulis menempatkan tujuannya dengan membuat sistem informasi manajemen kompalin costumer untuk membantu dan mempermudah costumer dalam mengadukan keluhan kepada PT Duta Abadi Primantara Pangerang.

\section{HASIL DAN PEMBAHASAN}

Perancangan sistem yang diusulkan ini yaitu untuk meningkatkan proses penanganan keluhan konsumen dengan cara memenuhi kebutuhan-kebutuhan sistem yang tidak dapat ditemukan pada sistem sebelumnya atau pada sistem yang berjalan. Untuk menganalisis sistem yang diusulkan, penulis mengunakan software Visual Paradigm for UML 6.4 Enterprise Edition untuk menggambarkan usecase diagram, activity diagram, sequence diagram, dan class diagram.

Berikut adalah contoh usecase diagram yang menggambarkan Konsumen, Admin dan pimpinan dapat login dengan memasukan username dan password yang telah terdaftar dengan hak akses masing-masing pada sistem.

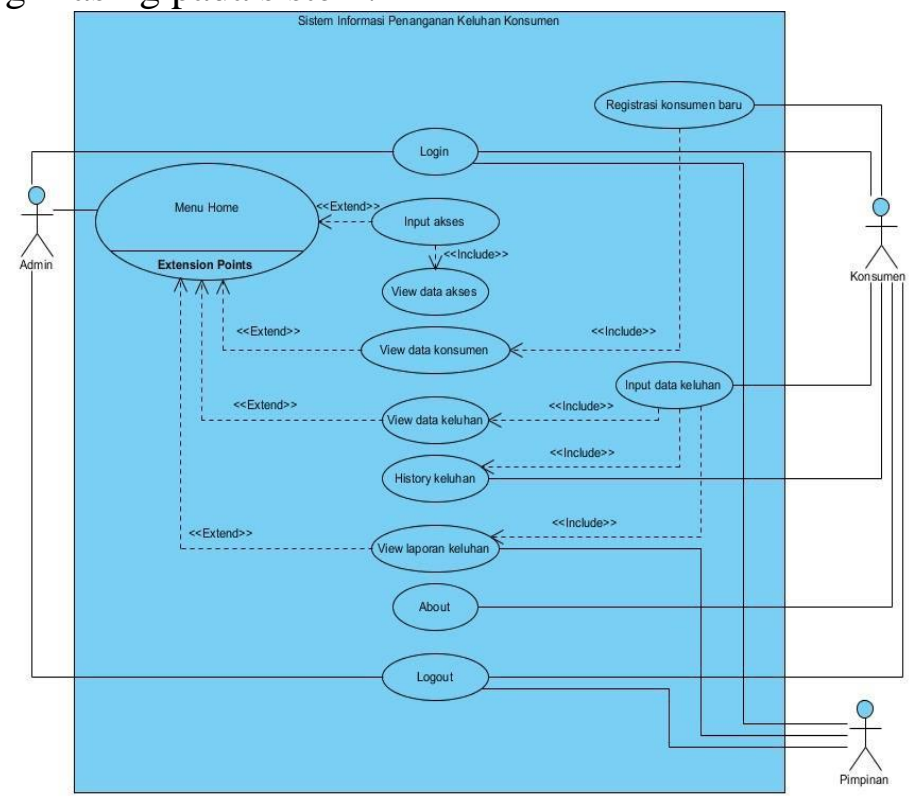

Gambar 1. Usecase Diagram yang diusulkan

Pada usecase diagram terlihat bahwa konsumen saat akan melaporkan keluhan yaitu melakukan registrasi terlebih dahulu jika sudah memiliki akun langsung melakukan login, melakukan input keluhan, melihat history keluhan dan penanganan, serta log out jika telah 
selesai, selain itu konsumen jg memiliki hak akses melihat data konsumen, melihat data keluhan.

\section{Activity diagram}

1. Activity diagram yang diusulkan untuk konsumen

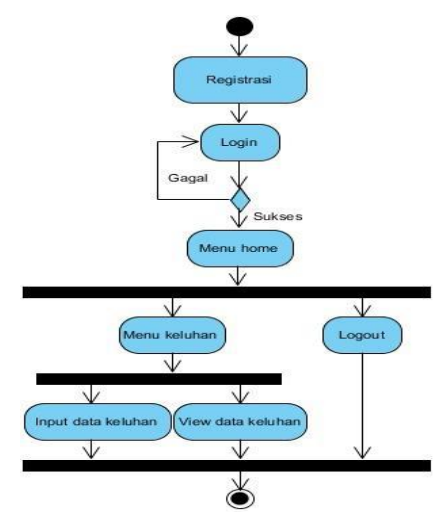

Gambar 2. Activity Diagram yang diusukan untuk Konsumen.

Pada activity diagram, Konsumen harus melakukan registrasi dengan login memasukan username dan password yang benar. Setelah berhasil login, konsumen akan dialihkan ke menu home. Selanjutnya, ke menu keluhan memasukan keluhan dan melihat hasil tanggapan keluhan.

2. Activity diagram yang diusulkan untuk admin

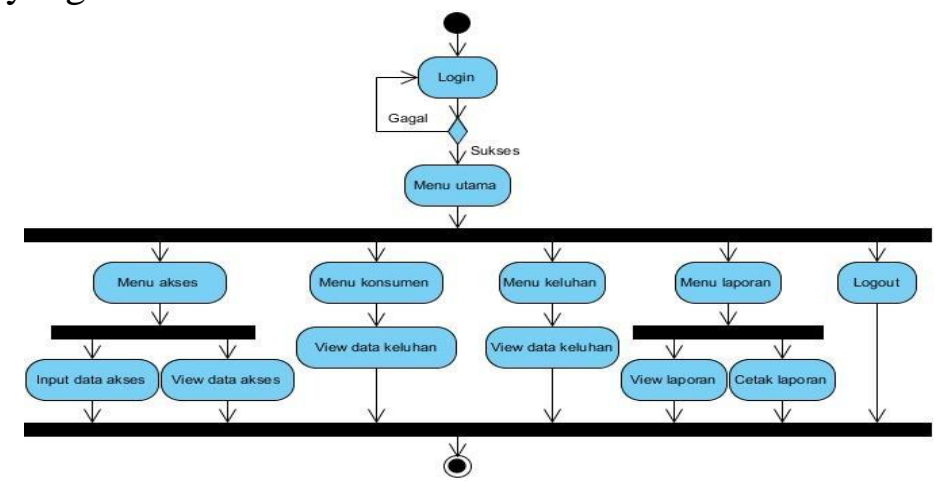

Gambar 3. Activity Diagram yang diusulan untuk Admin

Pada activity diagram, admin harus melakukan login terlebih dahulu dengan memasukan username dan password yang benar dengan hak akses dapat menginput, melihat, menyimpan dan mencetak keluhan yang akan dilaporkan terhadap pimpinan.

3. Activity diagram yang diusulkan untuk pimpinan 


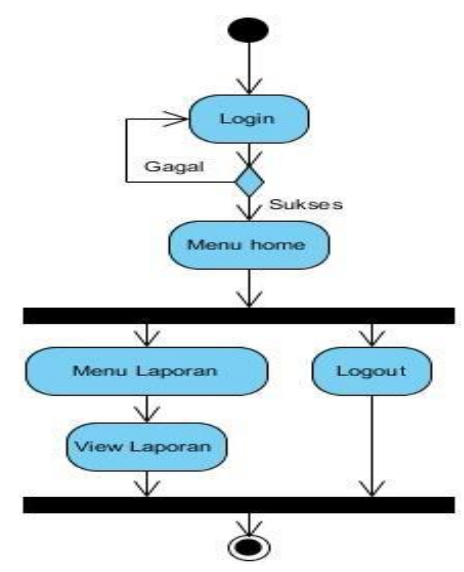

Gambar 4. Activity Diagram yang diusulan untuk Pimpinan

Pada activity diagram, pimpinan harus melakukan login dengan username dan password yang benar dengan hak akses dapat melihat laporan keluhan konsumen.

\section{Squence Diagram yang diusulkan}

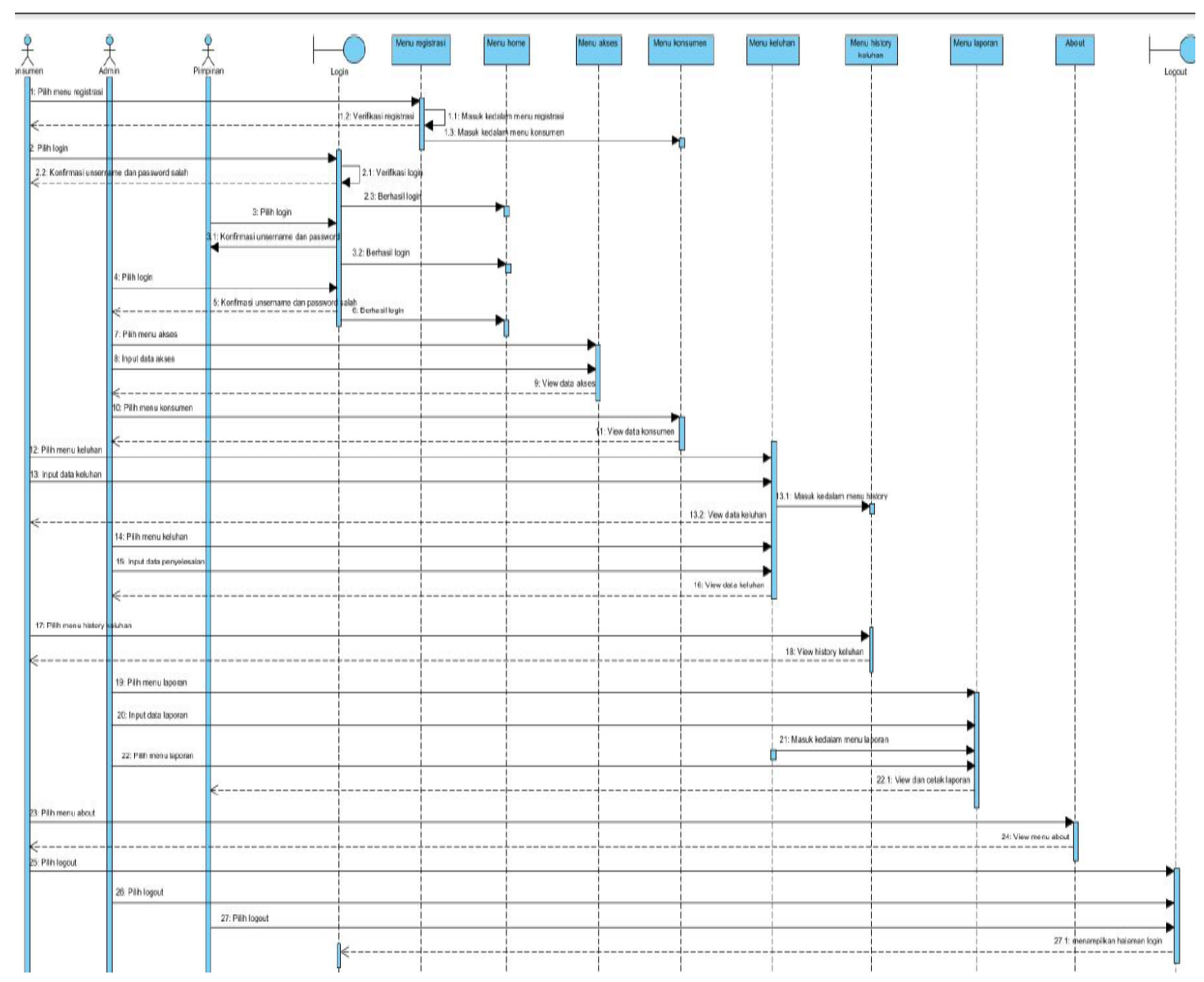

Gambar 5. Squence Diagram yang diusulan 
Pada sequence diagram, Aktor I (Konsumen) dapat melakukan login terlebih dahulu dengan memasukan username dan password yang benar. Setelah berhasil login, konsumen akan masuk ke menu dashboard. Selanjutnya, konsumen dapat menambah data keluhan .

Aktor II (Admin), dapat melakukan login terlebih dahulu dengan memasukan username dan password yang benar. Setelah berhasil login, Kemudian akan masuk ke halaman selanjutnya.

Aktor III (Pimpinan), dapat melakukan login terlebih dahulu dengan memasukan username dan password yang benar untuk dapat mengakses sistem.

\section{HASIL DAN PEMBAHASAN}

1. Menampilkan halaman menu login

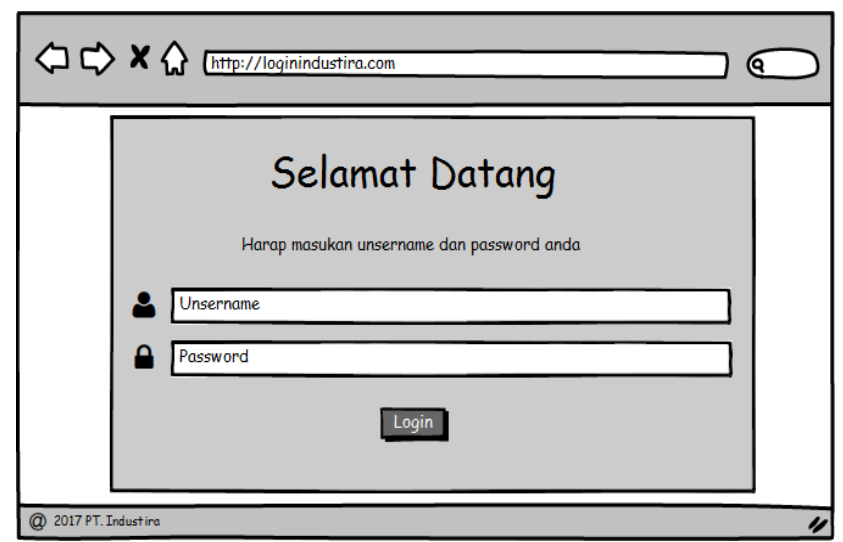

Gambar 6 Tampilan menu login pada user

User dengan benar selanjutnya klik login dan setelah itu user dapat masuk kedalam sistem. Sedangkan kalau username dan password salah maka tidak akan dapat masuk kedalam sistem dan akan muncul tulisan bahwa username dan password yang anda masukan salah.

2. Menampilkan Menu Home (Beranda)

Tampilan yang akan muncul jika sudah memalukan login.

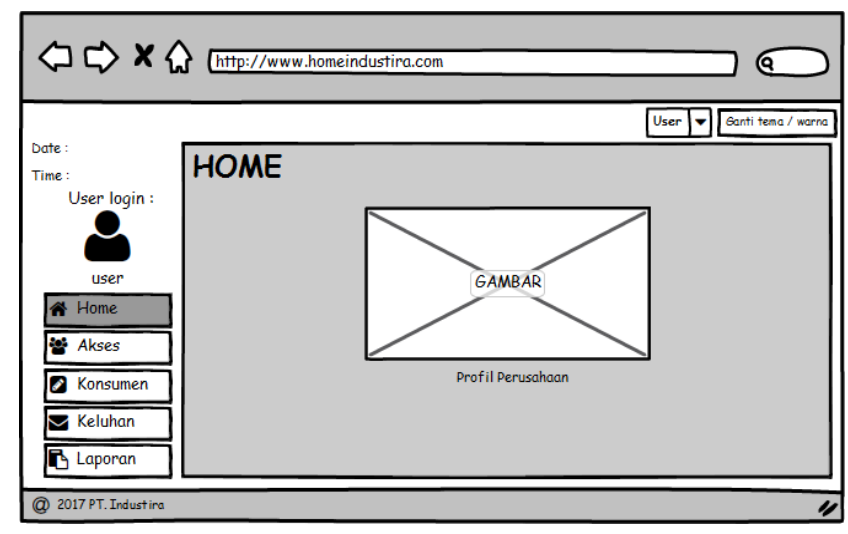

Gambar 7 Rancangan menu home pada user

3. Menampilkan Menu Tambah User 
Halaman ini berfungsi untuk menampilkan data user yang mengakses sistem penanganan keluhan konsumen.

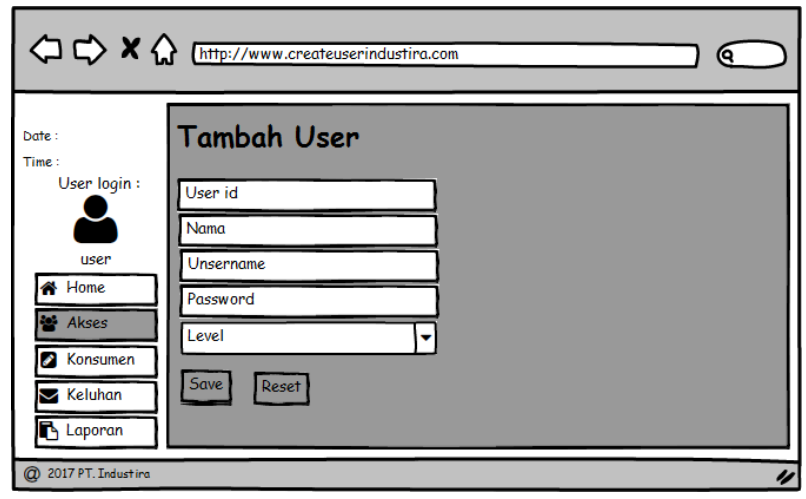

Gambar 7 Rancangan menu tambah user

dapat mengakses sistem klik save agar data tersimpan. Sedangkan button resert untuk mengulang data yang akan masukan sedangkan button close untuk menutup menu tambah user.

4. Menampilkan menu akses

Halaman ini berfungsi untuk menampilkan data konsumen yang telah melakukan registrasi dan yg memiliki akses penuh adalah admin

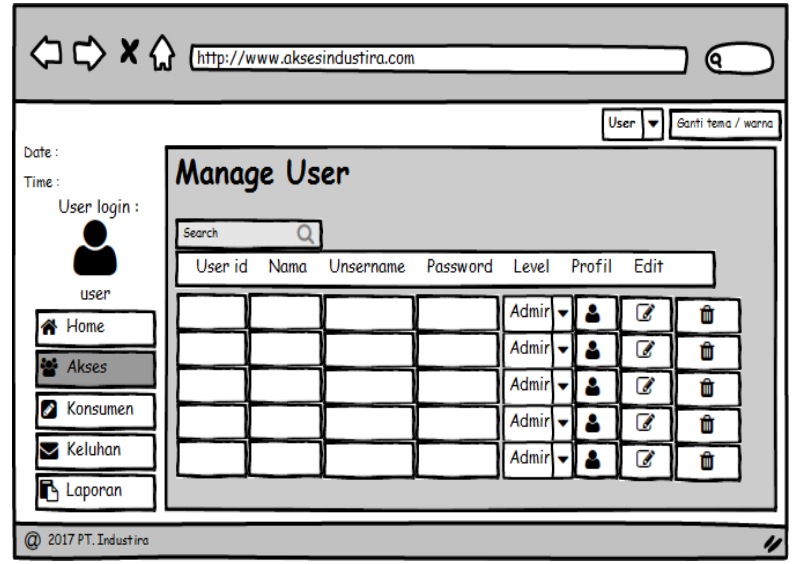

5. Menampilkan menu list konsumen

Gambar 8 Rancangan prototype menu akses

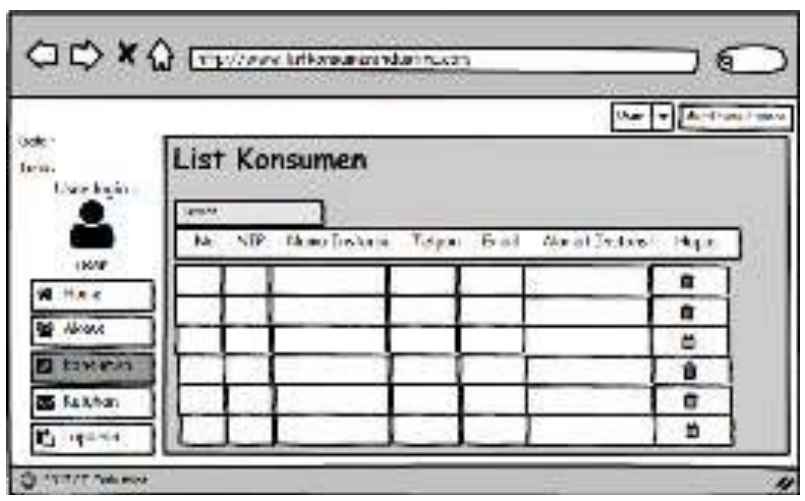


Gambar 9 menu list konsumen pada user

6. Menampilkan List Keluhan

Halaman ini berfungsi untuk menampilkan data keluhan yang telah diberikan oleh konsumen. Berikut ini adalah rancangan prototype menu keluhan pada user, menu penyelesaian, form analisa keluhan dan form tindakan dan pencegahan

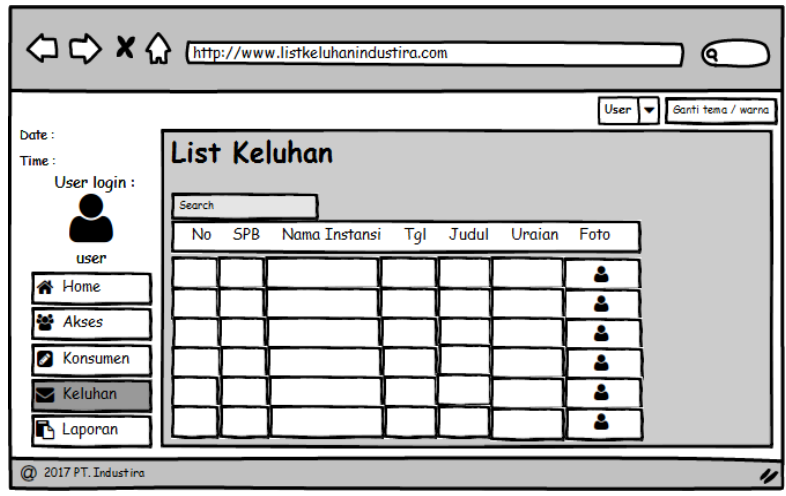

Gambar 9 prototype menu keluhan pada user

7. Menampilkan Menu Penyelesaian

Pada menu ini konsumen akan melihat sampai mana dan bagaimana penanganan keluhan yang dilaporkan, muali dari uraian, status, bagaiamana keluhan dikategorikan, serta tanggal penyelesaian

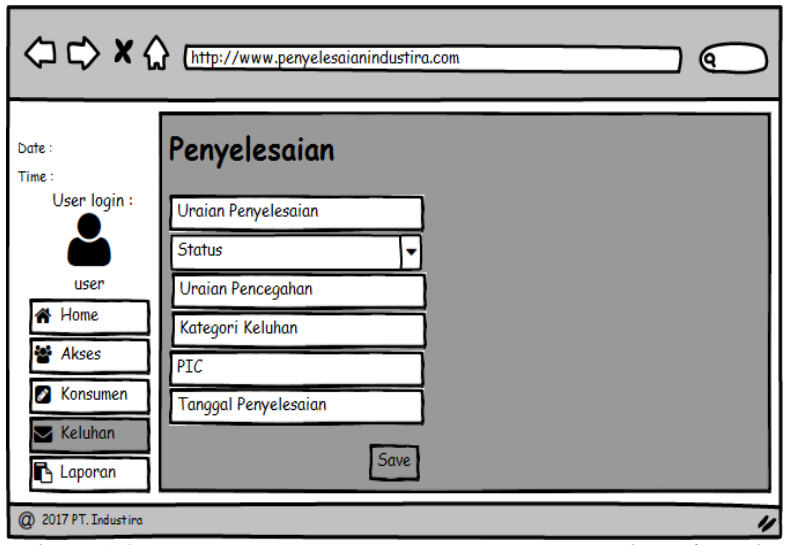

Gambar 10. Rancangan prototype penyelesaian keluhan

8. Menampilkan Form Analisa Kebutuhan

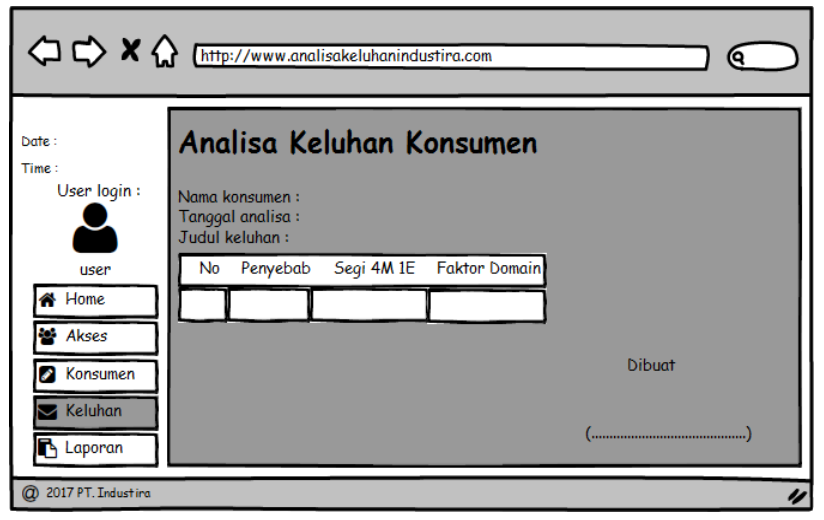


Gambar 11. Rancangan prototype analisa keluhan

9. Menampilkan Form Tindakan Pencegahan

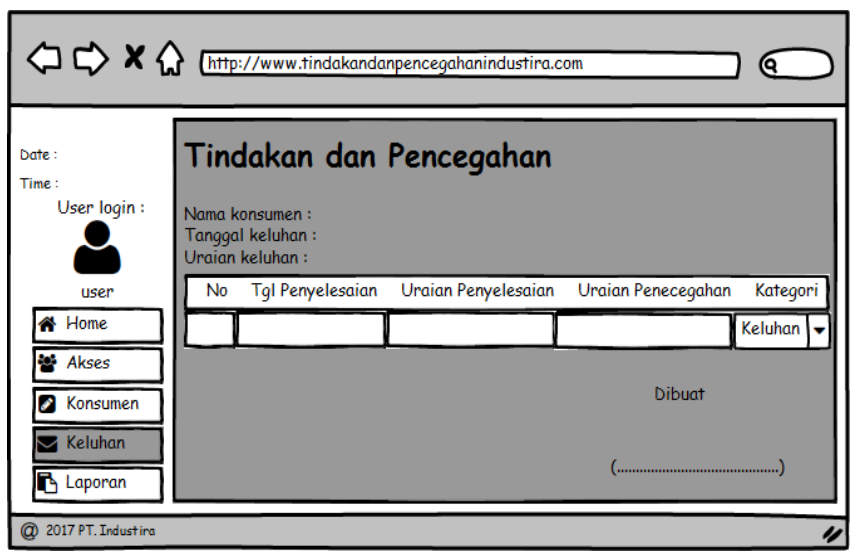

Gambar 12. Rancangan prototype form tindakan dan pencegahan

10. Menampilkan Form List Laporan

Halaman ini berfungsi untuk menampilkan laporan penanganan keluhan telah diberikan yang telah selesai. Berikut ini adalah rancangan prototype menu list laporan.

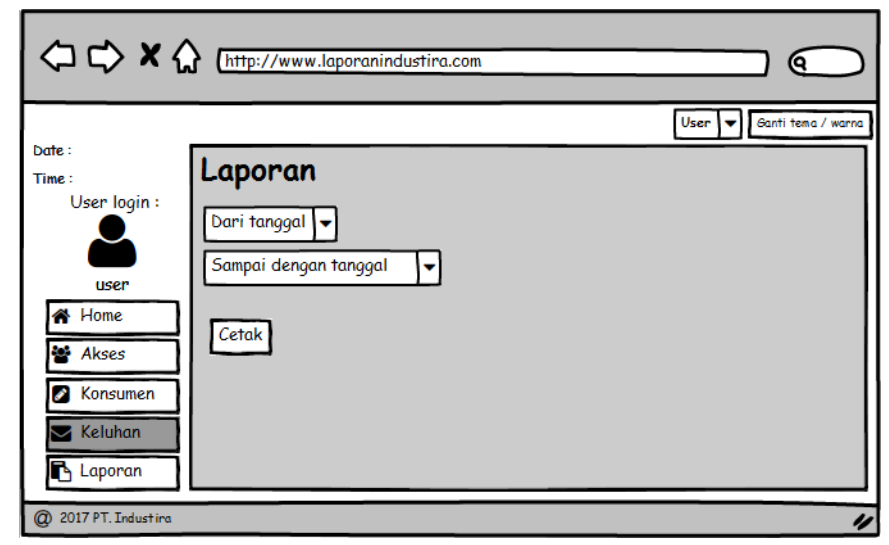

Gambar 13. Rancangan prototype form laporan

11. Menampilkan menu Cetak laporan

Apabila semua prosedur telah selesai dilakukan, maka selesai sudah penanganan laporan keluhan, dan hasil bisa dicetak pada menu cetak laporan

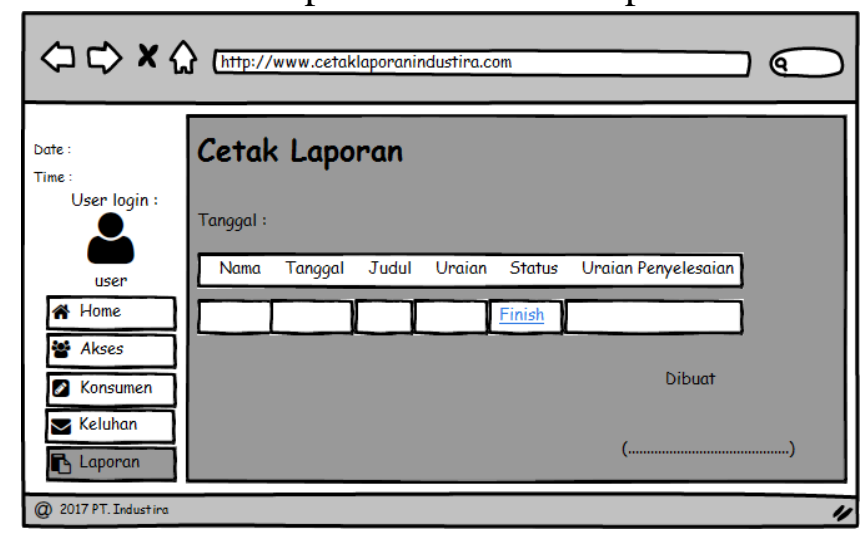


Gambar 14. Rancangan prototype form laporan

\section{Kesimpulan}

Berdasarkan pembahasan dari hasil penelitian dan analisis yang dilakukan oleh penulis mengenai perancangan sistem informasi penanganan keluhan konsumen berbasis web pada PT Industira Batu Ceper Tangerang, maka penulis mengambil kesimpulan sebagai berikut :

1. Sistem informasi penanganan keluhan konsumen pada PT Industira Batu Ceper Tangerang yang berjalan pada saat ini yaitu dalam penyampaian keluhan konsumen masih melalui telpon, setelah itu pihak perusahaan harus mencatatnya dalam daftar keluhan, lalu dalam proses menganalisa keluhan dan dalam pembuatan laporan masih dicatat manual, sehingga menimbulkan kesulitan dalam proses pengelolahan data untuk pembuatan laporan. Hal tersebut dikarenakan ketidakefektif dan ketidakefesienan dalam penyampaian keluhan, penampungan keluhan, pengolahan data keluhan, pengambil keputusan sampai dengan penyusunan laporan keluhan konsumen masih dalam pencatatan sehingga dalam penyajian informasilaporan memakan waktu yang lama.

2. Dalam merancangan sistem informasi penanganan keluhan konsumen pada PT Industira Batu Ceper Tangerang menggunakan metode analisis dan perancangan berorientasi objek dengan alat bantu Unified Modeling Language (UML), dibangun dengan bahasa pemrogaman PHP dengan database MySql. Dengan adanya sistem penanganan keluhan yang terkomputerisasi dapat mempermudah pihak perusahaan dalam pencarian keluhan yang diperlukan, mengetahui jumlah keluhan yang disampaikan oleh konsumen, proses keluhan yang ditangani dan hasil laporan penaganan keluhan.

\section{DAFTAR PUSTAKA}

[1] Adhista, Nova. Nur, Azizah. dan Rahayu, Sri. 2017. "perancangan sistem informasi penilaian kinerja karyawan SPG berstatus Kontrak pada PT. Softex Indonesia menggunakan metode Simple Additive Weighting (SAW)". Perguruan Tinggi Raharja: Jurnal Stategic of Education In Information System (SENSI) Vol. 3

[2] Budianto. Wahyu, Ageng. Setiani. Rafika, dan Mukti. Budiarto. 2015. "Aplikasi Monitoring Sistem Absensi Sidik Jari Sebagai Pendukung Pembayaran Biaya Pegawai Terpusat Dengan SAP”.Tangerang: Jurnal CCIT Vol.8 No.3

[3] Amrullah, Agit dkk. 2016. "Kajian Kebutuhan Perangkat Lunak Sistem Informasi Penilaian Prestasi Kerja Pegawai Pada Fakultas Adab dan Ilmu Budaya Universitas Islam Negeri Sunan Kalijaga Yohyakarta.” Yogyakarta: Seminar Nasional Teknologi Informasi dan Multimedia. 
[4] Bilung, Septinor. 2016. "Analisis SWOT dalam Menentukan Strategi Pemasaran Sepeda Motor Honda pada CV. Semoga Jaya di Area Muara Wahau Kabupaten Kutai Timur”. eJournal Administrasi Bisnis: Vol. 4, ISSN 2355-5408. 